\title{
The Normative Isomorphism of Language, Nation, and State
}

Tomasz Kamusella

\section{Introduction}

Language (written and standardized) is of crucial ideological importance for, arguably, all nationalisms in Central and Eastern Europe (including the four Visegrad states that form the core of this region). It constitutes the very basis of these nationalisms, which permits to speak of ethnolinguistic nationalism as the prevalent form of nationalism in this part of Europe. Significantly, in no other region in the world ethnolinguistic nationalism has become the norm of doing politics, and also of statehood and peoplehood formation and legitimization. (This does not preclude the fact that a handful of ethnolinguistic nation-states, such as Iceland, Japan or Vietnam are strewn elsewhere across the globe. However, these do not cluster tightly into a group of geographically adjacent politics, as ethnolinguistic nationstates do in Central and Eastern Europe.)

On the other hand, language plays $a$ role (though not the foundational one) in most other extant nationalisms. Thus, the problem is how to assess what constitutes an example of ethnolinguistic nationalism, which one is a borderline case, and in which nationalism language does not play a leading role. The concept of the normative isomorphism of language, nation, and the state provides a tool for conducting such an assessment, and also for 'measuring' the dynamics of a given ethnolinguistic nationalism.

\section{The Concept of the Normative Isomorphism of Language, Nation, and State}

This isomorphism is 'normative,' because nations and polities seeking legitimacy through their espousal of ethnolinguistic nationalism must meet, or, at least, aspire to meet, the isomorphism's requirements. The very meeting of these requirements is necessary for the achievement of a tight ideological and spatial overlapping of language, nation, and state that, in the framework of ethnolinguistic nationalism, are construed as separate or discrete (though related, or relate-able) entities.

First of all, each member of a nation has to speak the same (thus, national) language (usually, a standard enshrined in the state- or national academia-approved grammars and 
dictionaries). In this manner, each ethnolinguistic nation is defined and often imagined that it had existed through the agency of its language long before achieving its nation-state. Second, the national language cannot be shared with any other nation. Third, this language must be the sole official language of the nation's nation-state. Fourth, it cannot function as an official language in any other polity. Fifth, no autonomous regions with other official languages than the national one can exist on the territory of the nation-state in question. And by extension, sixth, no autonomous region with this national language as its official can exist in other polities.

Besides these necessary conditions of the normative isomorphism, one can also add further ideal ones, which are not deemed necessary, due to the sheer near-impossibility of achieving them. First, the members of an ethnolinguistic nation should be monolingual, that is, ought not to be able to speak any other languages than their national one. Second, all of them should permanently reside in their own nation-state. And, last but not least, no members of other nations should be allowed to live on a permanent basis in the nation's nation-state (Kamusella 2009: 29-36).

\section{The States Fulfilling the Normative Isomorphism in Central and Eastern Europe}

This normative isomorphism was probably impossible to achieve before the rise of the modern centralized state. Only such a state has at its disposal technologies and means of enforcing popular elementary education in the national language and full conscription draft of all males into the army that employs the national language; these have been the two main instruments of creating and maintaining homogenous monolingualism in a polity. The centralized state with an efficient bureaucracy can also impose almost a total control of its borders, with an eye to retaining speakers of the national language in the policy (and attracting them from outside, too), and to keeping speakers of other languages out (or expelling those who already happen to live in the state).

Not surprisingly then, no ethnolinguistic nation-state fulfilling the isomorphism's conditions existed in Central and Eastern Europe before World War I. A certain exception to this statement is the earlier founding of the aspiring ethnolinguistic nation-states in the Balkans during the 19th century, namely, Albania, Bulgaria, Greece, Montenegro, Serbia, and Romania. But then, to a degree, Montenegro and Serbia used the same language, which under the name of Serbo-Croatian they also shared with the Croats living in Austria-Hungary. In 
various territories outside Bulgaria and Greece, Bulgarian and Greek were employed for ecclesiastical, educational and local administration purposes. Likewise, outside Romania the Romanian language was used for the same purposes in Austria-Hungary's Transylvania (nowadays in Romania) and Russia's Bessarabia (or today's Moldova). These leave Albania as the model ethnolinguistic nation-state of that time, though shortly after its establishment in 1912-1913, in the course of the First World War, it was divided among foreign occupying forces and different local centers of power with variegated language regimes. But by looking up north to Scandinavia, which admittedly pushes the limits of what one is used to calling Central and Eastern Europe, one can point to Norway as a genuine ethnolinguistic nation-state fulfilling the isomorphism. (Although a specialist may note that there are two distinctive Norwegian languages, construed as equal varieties.) At that time, Sweden shared its official Swedish language with Russia's autonomous Grand Duchy of Finland, while on the other hand, Denmark was (as it is still today) a miniature empire, including, Greenland, the Faroese and Iceland, where local populations have tended to speak and write languages other than Danish.

Furthermore, the German Empire founded in 1871 as an ethnolinguistic German nation-state was frustrated in its ethnopolitical aspirations by the existence, outside its borders, of other polities with German as their official or national language, for instance, Austria-Hungary, and Switzerland. The situation continues to this day, as German is shared as an official and national language of Austria, Belgium, Germany, Liechtenstein, Luxembourg, and Switzerland (also by Namibia before 1990). The Italian nation-state faces a similar debacle, as, since its inception in 1861, it has shared its national language with San Marino and Switzerland (and later with the Vatican, too, officially recognized as a state by Italy in 1929). Likewise, the Netherlands did not then and still has not met the isomorphism's requirements, because it has shared Dutch in an official capacity with Belgium. It could be argued, however, that Dutch was not an official language in Belgium before 1898, which means that between 1830 and 1898, the Netherlands was an ethnolinguistic nation-state that met the requirements of the isomorphism.

Hence, bearing in mind the aforementioned qualifications, one can say that one state, the Netherlands, fulfilled the isomorphism until 1898 (especially, if one chooses to forget about the polity's seaborne empire), and two, namely Albania and Norway, immediately prior to 1914 , while Bulgaria and Romania were very close to achieving this ideal. 


\section{Between the Two World Wars}

After 1918, Central and Eastern Europe was reorganized on the (ethnolinguistic) national principle in the wake of the carving up of the non-national, multiethnic polities of Austria-Hungary and the Ottoman Empire. The German and Russian empires (which were of a similar multiethnic character) were pushed away from the region, the latter evolving into the Soviet Union, and the former into a de facto republic, despite officially preserving its old imperial name until 1945.

In the interwar period the following ten nation-states fulfilled the isomorphism's requirements: Norway (official language: Norwegian), Estonia (Estonian), Latvia (Latvian), Lithuania (Lithuanian), Czechoslovakia (Czechoslovak), Hungary (Hungarian), Romania (Romanian), the Kingdom of Serbs, Croats and Slovenes (since 1929 - Yugoslavia; Serbocroatoslovenian or, unofficially, Yugoslavian), Bulgaria (Bulgarian) and Albania (Albanian).

Swedish was instituted as a co-official language alongside Finnish in independent Finland, which excluded this country and Sweden from the exclusive club of polities meeting the criteria of the isomorphism. Poland almost achieved this goal, except for the fact that Polish was co-official in Soviet Belarus, alongside Belarusian, Russian and Yiddish. Greek continued to be used in an official capacity outside Greece, for example, in Italy's Dodecanese Islands and Britain's Cyprus; and Turkish was co-official on the latter island, too (Kamusella 2006: 60-78).

\section{World War II}

The picture changed dramatically in the course of the Second World War, due to the division of Central and Eastern Europe between the Third Reich (that is, national socialist Germany) and the Soviet Union, shortly followed by a total war between these former allies. Also, Italy had already annexed Albania.

First, Bulgaria, Hungary, Norway, and Romania survived as polities fulfilling the isomorphism, despite considerable changes in their territories (with the exception of Norway occupied by German troops). But the co-official use of Hungaro-Ruthenian (that is, Rusyn) in Hungary's Carpathia (that is, Czechoslovakia's former Subcarpathian Ruthenia) disqualified the state from this club. 
Two new states came into being in the wake of the destruction of Czechoslovakia in 1939 and Yugoslavia in 1941, namely Slovakia and the Independent State of Croatia with Slovak and Croatian, respectively, as their sole national languages. Thus, five polities fulfilled the isomorphism in the wartime, namely, Bulgaria, Croatia, Norway, Romania, and Slovakia.

\section{Cold War Europe (1945-1989)}

After World War II, Norway, Romania and Bulgaria continued to meet the isomorphism's requirements. They were joined by Albania, Hungary, and Poland. Czechoslovakia and Yugoslavia were recreated as, respectively, bilingual (Czech and Slovak) and multilingual (Albanian, Macedonian, Serbo-Croatian, and Slovenian) polities that eventually became federations. In 1974 Albania was excluded from the isomorphic group, because Albanian became a co-official language, alongside Serbo-Croatian, in Serbia's autonomous province of Kosovo. The same fate met Hungary and Romania, as Hungarian and Romanian were made co-official in Serbia's autonomous province of Vojvodina. Likewise, the 1960 transformation of British Cyprus into an independent nation-state with Greek and Turkish as its co-official languages continued to exclude Greece and Turkey from this group. So, as few as three polities fulfilled the isomorphism in the Cold War years, namely, Bulgaria, Norway, and Poland.

\section{After Communism (1989-Today)}

The subsequent break-ups of the Soviet bloc, the Soviet Union, Czechoslovakia and Yugoslavia dramatically altered the political division of Central and Eastern Europe. And until 2010 the following thirteen nation-states fulfilled the normative isomorphism in Central Europe, namely, Norway, Estonia, Latvia, Lithuania, Poland, the Czech Republic (Czech), Slovakia, Hungary, Romania, Slovenia (Slovenian), Montenegro (Montenegrin), Macedonia (Macedonian) and Bulgaria.

Serbia shares its national language of Serbian with Kosovo and Bosnia. In Kosovo also, Albanian is an official language, which disqualifies Albania from the isomorphic club. Croatia with its Croatian language and Bosnia with its Bosnian language could qualify, except that Croatian and Serbian are also co-official in the latter polity.

Belarus with its Belarusian language met the isomorphism's requirements between 1991 and 1995 before Russian became a co-official language in the state. Ukraine with 
Ukrainian as its official language almost managed to join the isomorphic club, but in the nation-state's autonomous Crimea Ukrainian has to share its official status with Russian and Tatar. (After Russia's internationally unrecognized annexation of Crimea in 2014, Ukraine became a de facto isomorphic nation-state.) Also, Moldova with its Moldovan language was close to achieving this goal, but an attempt at a union with Romania and at the (later retracted) renaming of the Moldovan language as Romanian, brought about a violent conflict in 1992 that led to the creation of the unrecognized polity of Transnistria (with Moldovan, Russian and Ukrainian as co-official languages) and the autonomous region of Gagauzia (with Gagauz, Moldovan and Russian as co-official languages).

Last but not least, in 2010 autonomy was reintroduced in Serbia's autonomous province of Vojvodina, complete with (at present) its six co-official languages (Croatian, Hungarian, Romanian, Rusyn, Serbian and Slovak). This meant the exclusion of Hungary, Romania and Slovakia from the tally, reducing the number of states currently (2013) fulfilling the isomorphism (Kamusella 2006: 56-60).

\section{States Fulfilling the Isomorphism Elsewhere in the World}

There are some ethnolinguistic nation-states fulfilling the isomorphism's requirements elsewhere in the world, too, however all of them are confined exclusively to Eurasia. Iceland with Icelandic in Western Europe, and in Asia, such polities include, Bhutan (Dzongkha), Cambodia (Khmer), Indonesia (Indonesian), Japan (Japanese), Laos (Lao), the Maldives (Maldivian), Thailand (Thai), Turkmenistan (Turkmen), Vietnam (Vietnamese). Malaysia was close to the ideal, but for the recent use of English in its educational system and the fact that it shares its official language with Brunei and Singapore. The two Koreas, if they were reunited, thanks to their common Korean language they would also qualify for the isomorphic club (bar the complication of China's Yanbian Korean Autonomous Prefecture, where Korean is a coofficial language). All other extant nation-states either share its official language with another polity, have more than one official language, or include an autonomous region with a language other than the state's national or official one.

Out of the total of twenty ethnolinguistic nation-states meeting the requirements of the normative isomorphism, nowadays (2013) ten are located in Central and Eastern Europe, nine in Asia and one in Western Europe. This statistics clearly indicates that while the isomorphism is the norm of politics, nationhood and statehood in Central and Eastern Europe, 
the employment of ethnolinguistic nationalism to this end is quite unusual elsewhere in the world. Although outside Central and Eastern Europe, Southeast Asia, with its five isomorphic polities, presents with itself the second most important locus of ethnolinguistic nationalism in the world. And, due to the inclusion of Indonesia, with its 238 million inhabitants, in this group, actually more people live in polities fulfilling this normative isomorphism in Southeast Asia than in Central and Eastern Europe (Kamusella 2016).

Out of the ten isomorphic nation-states in Central and Eastern Europe, seven employ Slavic languages in an official capacity, namely, Bulgaria, the Czech Republic, Macedonia, Montenegro, Poland, Slovenia, and Slovakia. This allows proposing that the ethnolinguistic kind of nationalism is typical of the Slavic nations and their nationalisms (Kamusella 2006: 90-92). Interestingly, in the isomorphic club, the languages of Bulgarian and Macedonian are almost fully mutually intelligible, as Czech and Slovak, and Lao and Thai (of the Tai language family) are, as well. By extending the purview to states that aspire, though thus far, have not managed to meet the isomorphism's requirements, the mutual intelligibility can be also observed in the cases of Indonesian and Malaysian (Malayan languages), Moldovan and Romanian, and of the (so far) four post-Serbo-Croatian languages (Bosnian, Croatian, Montenegrin and Serbian). Hence, in many instances, ethnolinguistic nationalisms are a product of the 'narcissism of small differences,' when a hardly perceptible variation is purposefully taken and deepened as the basis of two or more separate linguistic-cum-political projects.

\section{Human Costs of Achieving Ethnolinguistic Homogeneity}

Out of the aforementioned isomorphic polities, in reality, few are ethnolinguistically homogenous, while most are home to considerable percentages of citizens speaking languages different than the national one. The only exceptions are Iceland, Japan, and Poland. The two former polities share the same characteristic of being islands that for long periods of time were effectively sealed off from the outer world. And it is mainly (though not exclusively) this prolonged isolation that accounts for the emergence of ethnolinguistic homogeneity there. (Although in the case of the populous Japan the ethnolinguistic homogeneity is mainly a result of the centralized national educational system that levelled out any dialectal and linguistic differences during the $20^{\text {th }}$ century [cf Yeounsuk 2010].) In the case of Poland - the most populous state among the four Visegrad countries -- the state's ethnolinguistic homogeneity was achieved in the wake of the Holocaust (perpetrated by Germany) and of the 
huge changes in the postwar Polish borders (decided by the wartime Allies). These border changes entailed mass expulsions of Germans, Belarusians, Ukrainians and Jews from post1945 Poland, and were paralleled by returns of Poles from Germany and Western Europe and also by mass deportations of Poles from the enlarged Soviet Union to the new Poland.

Likewise, the very creation of ethnolinguistic nation-states in Central and Eastern Europe after 1918, changes in their territorial shape (including the erasure of some from the political map of Europe, and the emergence of brand-new nation-states) during World War II, their re-establishment after 1945, and the new wave of founding such states after 1989, required time and again huge population 'transfers,' often accompanied by a staggering number of casualties (Engel 1967: 194-195). For instance, between 1939 and 1948 alone, five million Jews and about half a million Roma were exterminated in the Holocaust, while 47.5 million people were temporarily or permanently resettled and expelled across Central and Eastern Europe (Magocsi 2002: 189-193).

Obviously, not all the Second World War killings, expulsiosn and resettlements were directly connected to achieving the ideal of ethnolinguistic homogeneity, but most, in an indirect or direct fashion, contributed to this end (cf. Snyder 2010). Thus, the unprecedented human cost of achieving genuine ethnolinguistic homogeneity in a nation-state, perhaps, deters most politicians from pursuing this goal, even if they stand fast by the ideals of ethnolinguistic nationalism.

\section{References}

Engel, J. (ed.) (1967) Grosser historischer Weltatlas (Vol 3: Neuzeit), Munich: Bayerischen Schulbuch-Verlag.

Kamusella, T. (2006) "The Isomorphism of Language, Nation, and State: The Case of Central Europe“", in Burszta, W., Kamusella T. and Wojciechowski, S. (ed.) Nationalisms Across the Globe: An Overview of Nationalisms of State-Endowed and Stateless Nations (Vol 2: The World), Poznań, Poland: Wyższa Szkoła Nauk Humanistycznych i Dziennikarstwa, pp. 57-92.

Kamusella, T. (2009) The Politics of Language and Nationalism in Modern Central Europe, Basingstoke, UK: Palgrave.

Kamusella, T. (2016) “Are Central Europe, and East and Southeast Asia Alike?: The Normative Isomorphism of Language, Nation and State", in Hara, K. and Heinrich, P. (ed.) 
Standard Norms in Written Languages: Historical and Comparative Studies Between East and West, Tokyo: Joshibi University of Art and Design.

Magocsi, R. P. (2002) Historical Atlas of Central Europe ( A History of East Central Europe, Vol 1), Seattle: University of Washington Press.

Synder, T. (2010) Bloodlands: Europe Between Hitler and Stalin, London: The Bodley Head. Yeounsuk, L. (2010) The Ideology of Kokugo: Nationalizing Language in Modern Japan, Honolulu HI: University of Hawai'i Press. 